\title{
EDITORIAL
}

\section{Correction and Apology}

We were sorry to learn from Dr. Chaussinand that in the October number of Leprosy Review, we published in error for the second time a letter for Dr. De Souza Araujo, who is now deceased. Dr. de Souza Araujo had previously published a letter on the subject, but the one we received and which was published on pages 267 and 268 bore a recent date and we were misled into believing that it was entirely new and failed to notice that it was a repetition. Dr. Chaussinand had already replied to the first letter in our issue of October 1961 on pages 276 and 277. We apologise to Dr. Chaussinand for any distress caused to him by this error.

\section{The Forthcoming 8th International Congress of Leprology}

A letter has been received from the National Organizing Committee in Rio de Janeiro. This letter is reproduced here in full.

\section{"Dear Friend,}

\section{PROGRAM}

You will already have heard through International Journal of Leprosy that the 8th International Congress of Leprology will be held at Rio de Janeiro from the 12th to 20th September 1963, in the Copacabana Palace Hotel.

\section{The Themes of the Congress}

A slight change has been made in the Themes for discussion in the Congress as compared to those in the last Congress. They will now be as follows:
A. Pathology and Experimental Transmission
B. Borderline and Indeterminate Leprosy
C. Leprosy Reaction
D. Therapy
E. Epidemiology
F. Bacteriology and Immunology
G. Education and Social Aspects
H. Physical Medicine and Rehabilitation, including Surgery and Vocational Training.

\section{The Panel System}

The panel system for detailed discussion by correspondence of each Theme beforehand will be maintained. Arrangements are under consideration for meetings before the Congress of 2 special Round Table Groups, one on Pathology and Experimental Transmission and the other on Borderline and Indeterminate Leprosy (the first two in the above list).

3. Papers

Papers from members will be of two kinds:

(a) requested papers from members of the panels 
(b) proffered papers from all full members of the Congress.

Please note that proffered papers must be presented in one of the official languages, viz. Portuguese, English, Spanish or French. This means that if you write in another language you must send also a translation in one of the official languages.

For presentation it is necessary to write the paper in 3 forms (a) an abstract of not more than 200 words which must be received by 12th July 1963, for publication in an Abstract Booklet to be issued to members before the beginning of the Congress; $(h)$ a shortened form of the paper which can be read in 10 minutes; $(c)$ the full paper (if this takes more than 10 minutes to read). The last two forms of the paper should be received before 12th June 1963. All papers in their various forms should be sent to Dr. Fausto Gayoso Castelo Branco, President of COCIL, (Rua São Cristóvão no. 1298 - Rio de Janeiro - Brasil).

Projection apparatus is available here and can take the following film and slide sizes. (Details not given).

\section{Registration}

The members will be entitled to take part in all the activities of the Congress, both scientific and social. The fee will be U.S. $\$ 10$ for members and $\$ 5$ for persons accompanying and $\$ 20$ for nonmembers and $\$ 5$ for persons accompanying them. These fees should be paid at the time of registration on the day preceding the Congress and the opening day.

\section{Languages}

The working languages of the Congress will be Portuguese, Spanish, English and French. Simultaneous interpretation will be provided throughout the sessions.

I shall be delighted to be at your service for any further information. I shall be glad if you will disseminate this information to your colleagues in your country and elsewhere. Also fill in and send the special registration form for accommodation required, as soon as you have made up your mind to participate. In this way you will contribute to the success of the 8th Congress by allowing of all arrangements to be in good time.

Looking forward to having the pleasure of hearing from you soon.

Dr. Fausto Gayoso Castelo Branco, Presidente da Comissao Organizadorado VIII Congresso Internacional de

$\mathrm{JAS} / \mathrm{ln}$. Leprologia (COCIL).”

\section{Further Information about Membership of Round Tables and Panels}

The full list is not quite complete, but it will be helpful if we give the names as far as we know them at present.

A. Round Table on Pathology and Experimental Transmission 
Chairman: R. J. W. Rees (U.K.)

Secretary: Prof. H. M. Portugal (Brazil)

Memhers: M. Bergel (Argentina), C. H. Binford (U.S.A.), Y. T. Chang (U.S.A.), K. R. Chatterjee (India), J. Convit (Venezuela), W. H. Feldman (U.S.A.), W. A. Hadler (Brazil), S. Nishimura (Japan), J. M. Robson (U.K.), C. C. Shepard (U.S.A.), F. F. Wilkinson (Argentina).

B. Round Table on Borderline and Indeterminate Leprosy

Chairman: R. D. Azulay (Brazil).

Secretary:

Members: R. G. Cochrane (U.K.), F. Contreras (Spain), Dharmendra (India), G. L. Fite (U.S.A.) T. Imaedo (Japan), W. H. Jopling (U.K.), V. R. Khanolkar (India), K. Kitamura (Japan), Gay Prieto (Spain), J. N. Rodriguez (Philippines),

F. Sagher (Israel), L. de Souza Lima (Brazil), H. W. Wade (President I.L.A. - Philippines).

\section{Panel on Reactions}

Chairman: F. Latapi (Mexico)

Secretary: D. S. Ridley (U.K.)

Members: E. A. Carboni (Argentina), J. Gomez Orbaneja (Spain),

C. K. Job (India), A. R. Mercau (Argentina), A. Rabello Neto Jr. (Brazil), J. Ramos e Silva (Brazil), P. Rath de Souza (Brazil), I. Tajiri (Japan), J. G. Tolentino (Philippines).

D. Panel on Therapy

Chairman: S. G. Browne (Nigeria \& U.K.)

Secretary: P. Laviron (France)

Members: A. M. Alonso (Brazil), A. Baccareda Boy (Italy), J. Barba Rubio (Mexico), M. B. Bhojwani (Malaya), T. F. Davey (U.K.), H. Floch (France), Latif K. Hanna (Egypt), Y. Hayashi (Japan), K. Ramanujam (India), K. F. Schaller (Ethiopia), S. Schujman (Argentina), M. F. R. Waters (U.K.).

E. Panel on Epidemiology and Control

Chairman: J. A. Doull (U.S.A.)

Secretary: A. Salazar Leite (Portugal)

Members: E. Agricola (Brazil), D. A. Akintonde (Nigeria),

L. M. Bechelli (Brazil), J. A. Kinnear Brown (U.K.), W. M.

Candidio (Brazil), O.Diniz (Brazil), C.Kettanurak (Thailand), D. L. Leiker (Netherlands), J. M. Mallac (India), F. E. Rabello (Brazil), C. M. Ross (U.K.), Amado Saul (Mexico).

F. Panel on Bacteriology and Immunology

Chairman: J. H. Hanks (U.S.A.)

Secretary: J. M. Fernandez (Argentina)

Members: J. O. Almeida (Brazil), R. S. Guinto (Philippines),

S. W. A. Kuper (U.K.), E. Montestruc (France), N. Olmos

Castro (Argentina), A. Rotberg (Brazil), Candido Silva 
(Brazil), K. Yanagisawa (Japan), Y. Yoshie (Japan), G. P. Youmans (U.S.A.).

G. Panel on Education and Social Aspects

Chairman: T. N. Jagadisan (India)

Secretary: Luiza Keffer (Brazil)

Members: C. Costa Neves (Brazil), C. I. Crowther (U.S.A.), M. C. Estrada (Mexico), R. Follereau (France), N. D. Fraser (U.K.), K. Hamano (Japan), O. W. Hasselblad (U.S.A.), E. B. Johnwick -(U.S.A.), R. V. Wardekar (India), Mrs. E. Weaver (Brazil).

H. Panel on Physical Medicine and Rehabilitation (including Surgery and Vocational Training)

Chairman: P. W. Brand (India \& U.K.)

Secretary: J. Arvelo (Venezuela)

Members: N. H. Antia (India), Mrs. Margaret Brand (India \& U.K.), J. E. Faggin (Brazil), M. Itoh (U.S.A.), M. Nakita (Japan), Mrs. Nimbkar (India), D. E. Paterson (India \& U.K.), E. W. Price (Nigeria \& U.K.), D. C. Riordan (U.S.A.), Linneau Silveira (Brazil), D. Ward (India), E. Zamudio (Mexico). 